\title{
EVALUATION OF THE GENETIC DIVERSITY AMONG MAIZE LINES (Zea mays L.) BY DNA FINGERPRINTING ANALYSIS
}

\author{
AVALIAÇÃO DE DIVERSIDADE GENÉTICA ENTRE LINHAGENS DE MILHO (Zea mays L.) \\ POR ANALISIS DE “DNA FINGERPRINTING
}

\author{
Sergio Echeverrigaray ${ }^{1}$ Ana Paula Longaray Delamare ${ }^{1}$ Geraldo Tosello $^{2}$ \\ Orit Gal $^{3} \quad$ Jossi Hillel $^{3} \quad$ Uri Lavi $^{4}$
}

- NOTA -

\section{SUMMARY}

\begin{abstract}
Informative DNA fingerprint profiles of eight homozygotic maize lines were obtained by the electrophoretic separation of DNA restriction fragments and their hybridization with the minisatellite probe RI8.1. The analysis of the bandsharing frequencies allowed to identify all the lines and to estimate the genetic distances between them. The relationship obtained by DNA fingerprinting analysis of the eight inbreed lines was highly consistent with their genetical origin.
\end{abstract}

Key wOrds: molecular identification, genetic distances, Zea mays.

\section{RESUMO}

Perfis altamente informativos de oito linhagens homozigotas de milho foram obtidos através de análise de DNA fingerprinting, hibridizando-se os fragmentos de restrição com a sonda minisatélite RI8,1. A análise de bandas coincidentes permitiu identificar todas as linhagens e estimar as distâncias genéticas entre elas. A relação entre as linhagens obtidas por esta análise é consistente com a origem genética das mesmas.

Palavras-chave: identificação molecular, distâncias genéticas, Zea mays.
In recent years, molecular marker techniques have gained widespread applications in many fields of plant genetics and breeding. Isozymes and restriction fragment length polymorphisms (RFLP) have provided valuable tools for linkage analysis and the establishment of genetic maps in all major crop plants, specially in maize (WALTON \& HELENTJARIS, 1987). The high number of genetic markers in reasonable frequencies and their presence in many germplasms makes RFLP a very useful method. However, the main limitation of RFLP is the high number of probes vs. enzymes that should be tested to obtain highly informative results, increasing the cost of the analysis. These problems can be overcome in several cases, by the use of multilocus probes in DNA fingerprinting analysis.

DNA fingerprint patterns have been obtained by the hybridization of mini and microsatellite probes to the nuclear DNA of several organisms including animals, plants and

\footnotetext{
${ }^{1}$ Instituto de Biotecnologia, Universidade de Caxias do Sul, Caixa Postal 1352, 95001-970, Caxias do Sul, RS, Brasil. Autor para correspondência.

${ }^{2}$ Departamento de Genética, Escola Superior de Agricultura "Luiz de Queiroz", Universidade de São Paulo, 13400-000 Piracicaba, SP, Brasil.

${ }^{3}$ Department of Genetics, Faculty of Agriculture, The Hebrew University of Jerusalem, 76100, Rehovot, Israel.

${ }^{4}$ Department of Horticulture Genetics and Breeding, Agricultural research Organization, 50250, Bet Dagan, Israel. 
microorganisms (HABERFELD, et al., 1991; NYBON, 1991). These sequences have been found to detect hypervariable regions (HVR) which provide highly polymorphic systems with a great potential as genetic markers. DNA fingerprinting have been used for the molecular characterization of the extent of variability within races, lines and cultivars; the assessment of the extent of inbreeding; the selection of maximal similarity to the recipient line during introgression programs; and the identification of genotypes allowing the protection of breeder's rights (WEISING, et al., 1991).

In the present study, eight homozygotic lines of maize (S12) belonging to three different genetic pools: 1-CDN-87, 2-CDN99, 3-CDN104 from the Normal Dent Compost (ESALQ/USP); 4-CFN1, 5CFN14, 6-CFN39 from the Normal Flint Compost (ESALQ/USP) and 7-SW-117, 8-SW134 from the Suwan Population, were analysed by DNA fingerprinting. Total DNA was prepared from 10 seedlings of each line using the CTAB method (MURRAY \& THOMPSON, 1980) and $10 \mu \mathrm{g}$ were digested with EcoRI, MvaI, HindIII or DraI. DNA was electrophoresed in $0.8 \%$ agarose $20 \mathrm{~cm}$ long gels on TBE buffer, run at $50 \mathrm{~V}$ for $24 \mathrm{~h}$ and blotted onto Hybond-N membranes (Amersham). Membranes were hybridized at $65^{\circ} \mathrm{C}$ for $16 \mathrm{~h}$ in $25 \mathrm{ml}$ of $6 \mathrm{x}$ SSC, $5 \times$ Denhardt's solution and $0.5 \%$ SDS. Low stringency washes were $2 \times \mathrm{SSC}, 0.1 \%$ SDS, twice at room temperature for $15 \mathrm{~min}$ and once at $65^{\circ} \mathrm{C}$ for $30 \mathrm{~min}$. Filter membranes were autoradiographed for $1-2$ days at $-80^{\circ} \mathrm{C}$ using Fuji-RXsafety films, in the presence of an intensifying screen. Probe used for the hybridization was R18.1 (EMBL Nucleotide Sequence Database $n^{\circ}$ X52968), a repetitive sequence of 1027 bp containing six poly (GT) stretches, isolated from a cattle genomic bank (HABERFELD \& HILLEL, 1991), was previously selected from other minisatellite probes $(33.6,33.15$ and M13) as the most informative for maize DNA fingerprinting. The probes were labelled with ${ }^{32} \mathrm{P}-\mathrm{dCTP}$ according to FEINBERG \& VOGELSTEIN (1984). The comparison between the profiles was done by the analysis of the bandsharing frequencies calculated by the following formulae: $\mathrm{BS}=(2 \mathrm{nAB}) /(\mathrm{nA}+$ $n B$ ), where $n A$ and $n B$ are the number of bands in each profile and $\mathrm{nAB}$ are the number of bands present in both lines (HABERFELD, et al., 1991).

Hybridization of probe R18.1 to digested maize DNA revealed a complex and characteristic DNA fingerprint pattern of each line, with a number of bands ranging from 27 to 35 according to the restriction enzyme used for genomic DNA digestion (Figure 1). In previous works it has been observed that the cattle derived probe R18.1 yield complex and highly polymorphic DNA fingerprint patterns in several farm animals (HABERFELD et al., 1991); in yeasts (ECHEVERRIGARAY et al., 1994) and in some plants (TZURI et al, 1991). These findings suggested that the poly GT minisatellite regions are widespread over most living organisms. In maize, the best patterns were obtained with DraI, EcoRI and HindlII, although the last two enzymes showed a concentration of high molecular weight fragments. The comparison between lines showed high polymorphism, giving a characteristic profile that allowed the identification of all the genotypes, even those of the same genetic origin. The profiles showed a high reproducibility in two different blots made with different DNA extractions.

The bandsharing frequency analysis of the profiles obtained with HindIII and EcoRI gave similar results with high correlation. Bandsharing frequencies ranging between 0.52 and $0.95(\mathrm{~m}=0.62$, s. $\mathrm{d} .=0.15)$ were obtained in the comparisons between lines of the

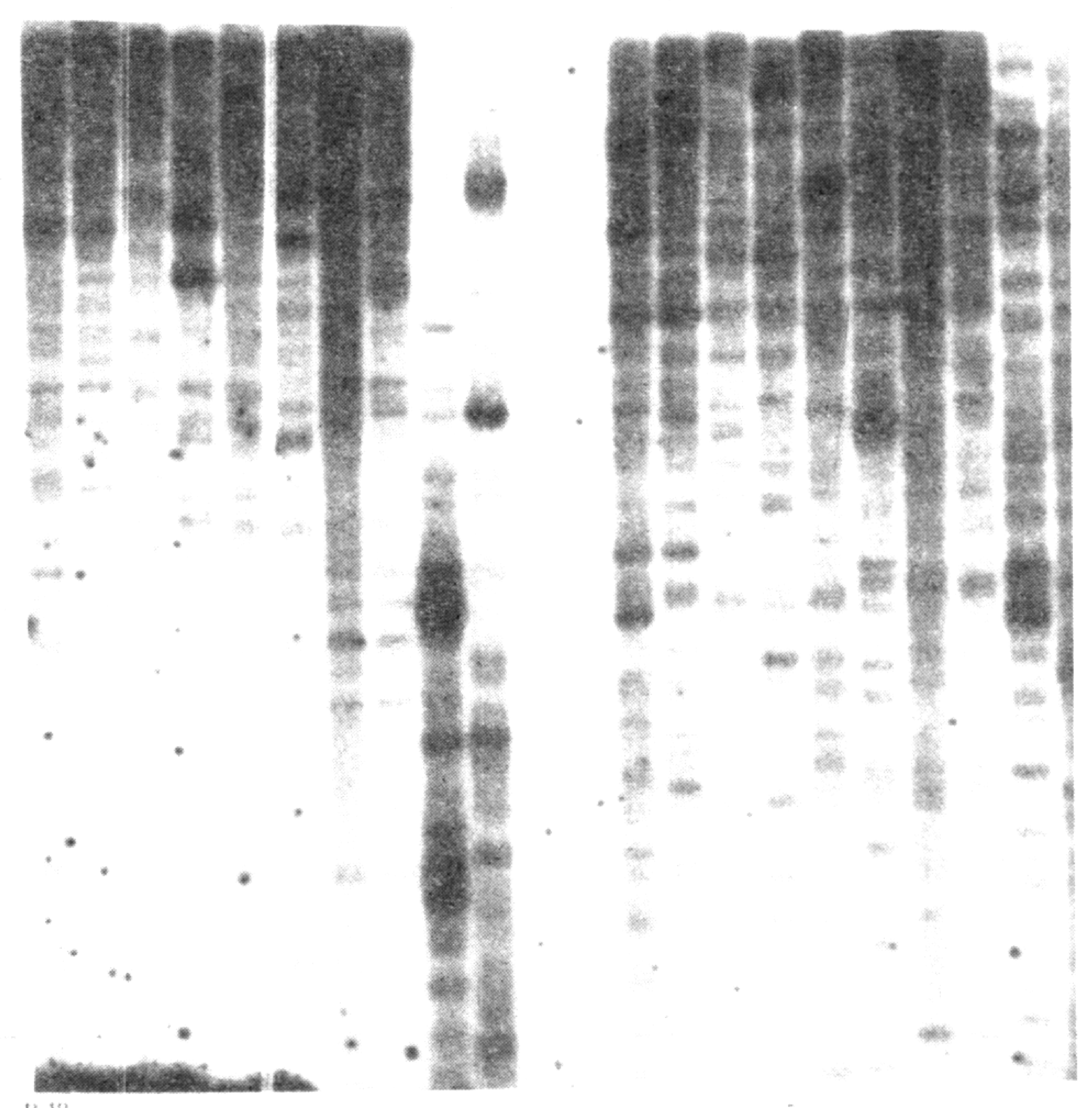

Figure 1. DNA fingerprint profiles of corn lines from three different genetic pools, using R18.1 minisatellite probe and four restriction enzymes (EcoRI, MvaI, HindIII and DraI). The Molecular weight pattern (left) corresponds to $2 / H$ indIII: $23,9.5,6.5$ and $2 \mathrm{~Kb}$. 
same origin, whereas the comparisons between lines of different origins yield bandsharing frequencies of 0.21 to $0.44(\mathrm{~m}=0.35$, s.d. $=0.07)$. As expected, the composts which have a larger genetic backgrown gave lines with lower bandsharing frequencies between them. The number of bands and the bandsharing frequencies are comparable to those obtained between carnation cultivars (TZURI et al., 1991) and poultry genotypes (HABERFELD et al., 1991).

The dendrogram (Figure 2) shows the arrangment of the lines in three groups which correspond to the different genetic sources. Although a higher number of lines should be tested, the correlation between the genetic diversity evaluated by DNA fingerprinting using R18.1 probe and the genealogical relationship between the lines, can be seen as a proof of the efficiency of this method for the analysis of genetic relations, and its potential as markers for different purposes in breeding programs.

\section{REFERENCES}

ECHEVERRIGARAY, S., TAVARES, F. C. A., GAL, O., et al. Minisatellite probes in yeast DNA fingerprinting. Rev Microbiol, v. 25, p. 207-209, 1994.

FEINBERG, A. P, VOGELSTEIN, B. A technique for autoradiolabelling DNA restriction endonuclease fragments to high specific activity. Analytical Biochemistry, v. 137, p. 266$267,1984$.

HABERFELD A., CAHANER, A., YOFFE, O, et al. DNA fingerprints of farm animals generated by microsatellite and minisatellite DNA probes. Animal Genetics, v. 22, p. 299-305, 1991.

HABERFELD A, HILLEL, J. Development of DNA fingerprint probes: an approach and its applications. Animal Biotechnology, v. 2, p. 61-73, 1991.

MURRAY A, THOMPSON, H. Rapid isolation of high molecular weight plant DNA. Nucl Acids Res, v. 8, p. 4321-4325, 1980.

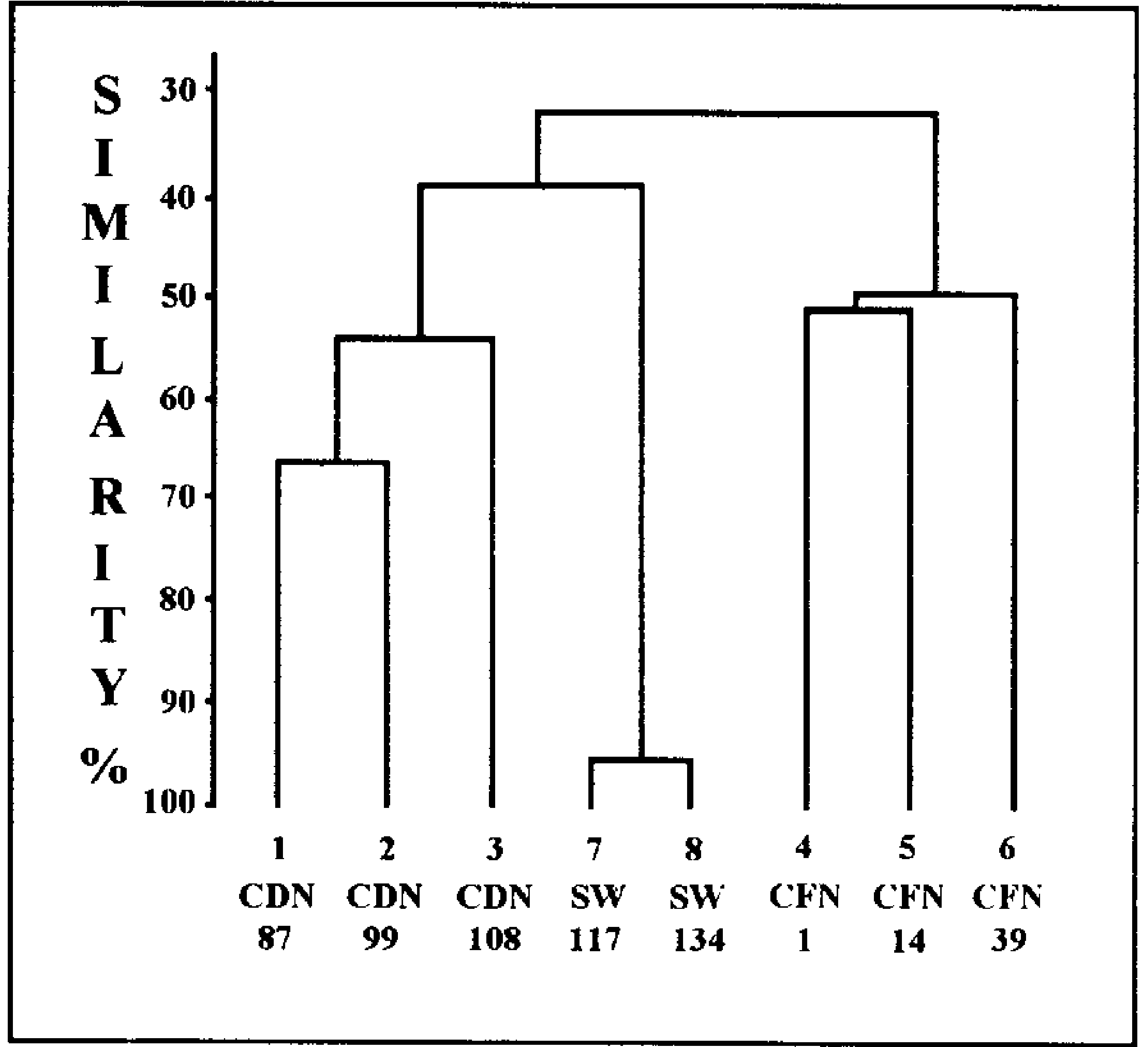

Figure 2. Dendrogram based on the comparison between R18.1/HindIII DNA finger print profiles of eight corn lines.

NYBOM, H. Applications of DNA fingerptinting in plant breeding. In: BURKE, T., DOLF, G., JEFFREYS, A. J., et al. DNA fingerprinting: approaches and applications. Basel, Switzerland: Birkhauser Verlag, 1991, p. 294-311.

TZURI, G., HILLEL, J., LAVI, U., et al. DNA fingerprint analysis of hornamental plants. Plant Science v. 76, p. 91 -97, 1991.

WALTON, M., HELENTJARIS, T. Application of restriction fragment length polymorphism (RFLP) technology to maize breeding. In: ANNU. CORN AND SORGHUM IND. RES. CONF., 1987. Chicago, IL. Proceedings... Chicago, IL, American Seed Trade Association, 1987. p. 48-75, 1987.

WEISING, W., RAMSER, J., KAEMMER, D., et al Oligonucleotide fingerprinting in plants and fungi. In: In: BURKE, T., DOLF, G., JEFFREYS, A. J., et al. DNA fingerprinting: approaches and applications. Basel, Switzerland: Birkhauser Verlag, 1991. p. 312-329. 